\title{
The Positive Politeness Analysis Used in Virgin-Meet the Author
}

\author{
Dewi Sartika $^{1}$, Ambalegin $^{2}$ \\ ${ }^{1}$ Pb171210012@upbatam.ac.id, 2Ambalegin@puterabatam.ac.id \\ ${ }^{1,2}$ Universitas Putera Batam (UPB)
}

\begin{abstract}
This research used qualitative research method. The theory used is Brown \& Levinson (1987) about 15 positive politeness strategies. The aim of this study was to find the positive politeness strategies in Virgin-Meet the Author. Virgin is a Youtube channel. This channel contains videos that can inspire others through the good videos that are in it. One of the inspirational episodes is the Meet the Author episode where the author can tell the audience the contents of the book she/he has made so that audience can understand the contents of the book. In collecting data, this study used observational method and non-participatory techniques. Pragmatic identity method used in this research to analyze the data. The result that the researcher found were strategy of using in group identity markers, avoiding disagreement, giving and asking for reasons, includes both speaker and hearer in activity and exaggerating strategy in Virgin-Meet the Author.
\end{abstract}

Keywords: politeness strategies, positive politeness strategies

\section{INTRODUCTION}

Language enables people to communicate whatever they can imagine. Language is very important in interacting with others. Language makes us easy to understand. Communicating is an important thing for someone to know how to make the conversation they make can run well and smoothly (Dharmayanti, Sukarini, \& Savitri, 2018). We need to be polite to communicate something. Politeness in speaking is very important. Ayuningrum, P, \& S (2018) said that the key to building good conversations and harmonious communication with others is politeness. Politeness is used in various aspects of life or in every field such as in politics and entertainment, education and other fields. It also influences how to respect other people. This politeness is also influenced by age, status, and so on. The example of politeness itself can be found in our daily life through social media, as below : 


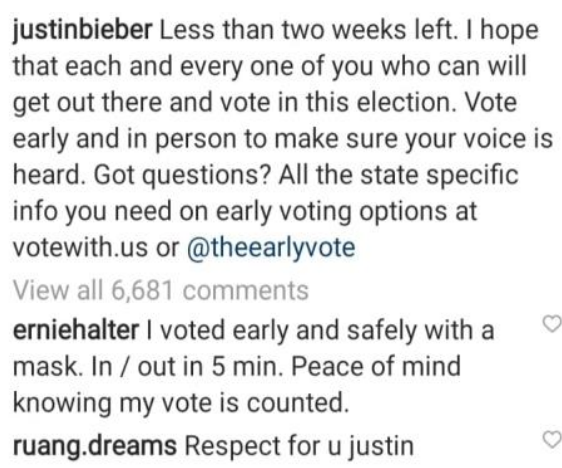

Figure 1. The example of politeness in social media

The example above found in@justinbieber's instagram comment when@ @ruang.dreams commented on his post by saying respect for u Justin. It can be included using in-group identity markers strategies because @ ruang.dreams called @justinbieber Justin where it was to make @justinbieber's felt comfortable and showed the identity marker of @justinbieber. Brown \& Levinson (1987) stated that using in-group identity markers is one of the positive politeness strategies.

Research on politeness strategies has several studies that examined this before. The first research was conducted by Safitri (2015). This study aimed to analyze the strategic politeness used by the characters in "The Big Wedding Movie ". The results of the analysis that have been done are 86 utterances that use the politeness strategies. Positive politeness, bald on-record, offrecord, and are frequently used but negative politeness is the less frequently used.

The second is from Kamlasi, (2017). The purpose of this study was to explain and determine the types of greetings with positive politeness and the percentage of greetings in student conversations. The results of this study, there are several positive politeness greeting terms found, these terms are greetings, thanking, praising, apology, congratulating, intimacy, obedience, question, request, suggestion, rejection, chastisement, and disagreement.

Positive politeness is something that has an important role in communicating with other people in any condition. This research was conducted because in everyday life positive politeness cannot be avoided either in direct communication or indirectly. This research related to the pragmatic. Yule (1996) stated pragmatics relates to how a context can affect a meaning, this means that a sentence can be interpreted according to certain conditions. This study analyzed "The Positive Politeness Strategies used in Virgin-Meet the Author".

Gaspie (2014) said that through a positive face shows that a person has a desire to be appreciated and approved by others. Positive politeness strategies are attempts to minimize threats to the listener's positive faces. According to Brown \& Levinson (1987) positive 
politeness itself has 15 strategies.

\section{Claim common ground}

Strategy 1: Notice, attend to hearer (his interests, wants, needs, goods)

Considering the conditions of hearer associated with this strategy. This strategy refers to interests, wants, needs, goods or anything the listener might want to pay attention to. In this strategy speaker can express this through praise to hearer in order to avoid a bad impression. For example is from Brown \& Levinson (1987) as below:

"What a beautiful vase this is! Where did it come from?"

Strategy 2: Exaggerate (interest, approval, sympathy with hearer)

Saving the hearer's positive face can be done by using exaggerated expressions by making things appear more important than they really are. Usually in this strategy, speaker will emphasize his feelings for hearer which may include the intention of approval and sympathy. For example is from Brown \& Levinson (1987) as below:

"What a fantastic garden you have!"

Strategy 3: Intensify interest to hearer

This strategy relates to how speaker attracts and increases hearer's attention and interest in what speaker is talking about by making a good story or narrative. For example is from Brown \& Levinson (1987) as below:

"I come down the stairs, and what do you think I see? - a huge mess all over the place, the phone's off the hook and clothes are scattered all over ..."

Strategy 4: Use in-group identity markers

Applying in-group identity markers is a good thing when talking to someone you are talking to because it can create a good relationship between speaker and hearer to avoid any facial threats. This strategy will usually use words like buddy, mate, sweetheart, guys and even the use of the name of the other person we are talking to. For example is from Brown \& Levinson (1987) as below:

"Here mate, I was keeping that seat for a friend of mine ..."

Strategy 5: Seek agreement

The purpose of this strategy is to find an agreement so that the topics discussed can continue and not be disturbed by giving hearer the possibility to agree. For example is from Brown \& Levinson (1987) as below:

A: John went to London this weekend! 


\section{B: To London!}

Strategy 6: Avoid disagreement

Avoiding any disagreement between speaker and hearer is a good thing to avoid any facial threats. Usually this strategy will not reveal directly that he does not agree with the statement of the interlocutor but will find a way to say this using kind words such as if possible, sort of, in a way and others. For example is from Brown \& Levinson (1987) as below:

A: Can you hear me?

B: Barely.

Strategy 7: Presuppose/raise/assert common ground

This politeness strategy creates, enlarges and emphasizes the similarities between speaker and hearer. This is done with various interests, beliefs and opinions between speaker and hearer. In this case speaker will make small talk that includes hearer in the conversation to build a communication. For example is from Brown \& Levinson (1987) as below:

"I had a really hard time learning to drive, didn't I."

Strategy 8: Joke

A joke is needed in this strategy because a joke can make hearer feel comfortable and usually the joke is made based on the knowledge and background between speaker and hearer. For example is from Brown \& Levinson (1987) as below:

"OK if I tackle those cookies now?"

\section{Convey that $S$ and $H$ are cooperators}

Strategy 9: Assert or presuppose speaker's knowledge of and concern for hearer 's wants.

Asserting and presuppose knowledge to hearer so that he can work together with speaker to fulfill what speaker wants. For example is from Brown \& Levinson (1987) as below:

"Look, I know you want the car back by 5.0, so should (n't) I go to now? (request)"

Strategy 10: Offer, promise

There are things that $\mathrm{S}$ did to hearer by offering something and giving a promise to avoid some FTAs. For example is from Archia (2014) as below:

Alan Cowan : His mouth will be fine when the swelling goes down. As for the teeth, if he needs it, we'd be willing to chip in for the best dental care...

Michael Longstreet: We got insurance for that.

Strategy 11: Be optimistic

This strategy has to do with how speaker is optimistic about what he says to hearer so 
that hearer can do it to him. For example is from Brown \& Levinson (1987) as below:

"You'll lend me your lawnmower for the weekend, I hope"

Strategy 12: Include both speaker and hearer in the activity

The word form used in this strategy is "We" by asking hearer to participate in the activity speaker wants. For example is from Brown \& Levinson (1987) as below:

"Let's have a cookie, then. (i.e. me)"

Strategy 13: Give (or ask for) reasons

Give and ask something with a reason related to this strategy. When speaker asked that he could be helped, he would pay attention to the reasonableness and reasons for that to hearer. For example is from Brown \& Levinson (1987) as below:

"Why not lend me your cottage for the weekend?"

Strategy 14: Assume or assert reciprocity

This strategy is related to the cooperation between speaker and hearer. Through this strategy there must be reciprocity between speaker and hearer by realizing what is the responsibility and right of both. For example:

"If speaker helps hearer to sweep the floor then hearer will help speaker to do her assignment and vice versa."

\section{Fulfill H's want for some $\mathbf{X}$}

Strategy 15: Give gifts to hearer (goods, sympathy, understanding, cooperation)

This strategy is related to how speaker can fulfill what the hearer's positive face wants . In this strategy, usually speaker will give gifts, sympathy and cooperation to the hearer because hearer has the desire to be admired, liked, cared for and so on. For example is from Archia (2014) as below:

A: Have a glass of malt whisky, Rick.

B: Terrific! Thanks.

A: Not at all. I wonder if I could confide in you for a minute or two.

\section{RESEARCH METHOD}

Researcher used descriptive qualitative research method in this study because the data used were in the form of words, phrases and sentences. Qualitative research method itself is method that has a descriptive to analyze a phenomenon more deeply (Cresswel, 2013). In collecting data, researcher used the observation method (Sudaryanto, 2015). Non-participatory 
is a technique in collecting the data the researcher uses it because the researcher does not interact with the speaker directly but only watches the video and analyzes the existing utterances. The research uses pragmatic identity method to analyze the data.

\section{FINDINGS AND DISCUSSION}

There were some strategies found in this study such as : 1) The strategy of using in group identity markers it can be found in the data $1 ; 2$ ) Avoiding disagreement can be found in data $2,4,5,6,7,8,11,12,13$ and 15;3) The strategy of giving and asking for reasons can be found in data 3 and 10;4) The strategy includes both speaker and hearer in activity can be found in the data $9 ; 5)$ The exaggerating strategy can be found in the data 14 .

\section{Data 1}

Host : Hello Mrs. Obama. Is it ok if I call you Michelle?

Michelle : of course, Holly. How are you? It's great to see you again.

Michelle's utterance is included in the strategy of use in-group identity markers. The conversation happened when Michelle agreed to the host's statement by saying of course, Holly. Holly here reflects the identity marker of the host.

\section{Data 2}

Host : It's absolutely brilliant. I'm not the only one who thinks it's great. You have sold two million copies in the US alone.

Michelle : Yeah.

Michelle's utterance above is included in the avoiding disagreement strategy. The conversation occurred when the host gave a statement about Michelle and Michelle agreed with the statement by saying yeah.

\section{Data 3}

Host : So that's why you're so good at this storytelling.

Michelle $\quad$ : It's probably part of the reason why I'm good at it.

Michelle's utterance is included in the strategy of giving or asking for reasons. The conversation happened when Michelle gave a reason why she was good at it when the host 
asked her.

\section{Data 4}

Host : I know, bringing up twins at the same time they get the exact same everything but they're completely different people.

Michelle: Right, and I think my parents understood that so they didn't expect the same thing from me as they did from my brother but they did treat us as equals which I think played a big role in me being a powerful woman with a powerful voice.

Michelle's utterance is included in the avoiding disagreement strategy. it happens when Michelle says right which indicates that she agrees with the host's statement.

\section{Data 5}

Host :Especially with the standardized testing and having to pass the exams and get on to the next level.

Michelle: Right, this notion that every kid is going to learn in the same way at the same time is disastrous and it creates box checkers who then go on to careers that may not fulfill them and then they're not good at it.

Michelle's utterance is included in the avoiding disagreement strategy. it happens when Michelle says right which indicates that she agrees with the host's statement.

\section{Data 6}

Host : It's such a young age...

Michelle: Exactly.

Michelle's utterance is included in the avoiding disagreement strategy. it happens when Michelle says exactly.

\section{Data 7}

Host : Yeah, you didn't call it 'Become'.

Michelle: That's right, 'Became', already done that

Michelle's utterance is included in the avoiding disagreement strategy. Saying that's 
right is indicates that she agrees.

\section{Data 8}

Host :The opposite attracting.

Michelle : Yeah, absolutely.

Michelle's utterance is included in the avoiding disagreement strategy. By saying yeah, absolutely, it indicates that she agrees.

\section{Data 9}

Host : Again it's very lucky that we both had parents that stayed together.

Michelle: Absolutely, and we see that. We're supposed to give others.

Michelle's utterance is included in the include both $\mathrm{S}$ and $\mathrm{H}$ in the activity strategy. It happens when Michelle says absolutely, and we see that. We're supposed to give others. Said "we" indicates that Michelle asks to host to participate to that activity.

\section{Data 10}

Host :Yeah. And it's definitely a love that's got you both through tough times. Especially the struggles getting pregnant and I've experienced miscarriages, I've been through IVF as well. Why did you feel you needed to share that bit of your life story which was very personal?

Michelle: $\quad$ For the same reason. We don't talk about those things and when I was in that position I wished I had more people who would tell me that it would be okay.

Michelle's utterance is included in the strategy of giving or asking for reasons. When Michelle says for the same reason it means that she gives a reason for it.

\section{Data 11}

Host : You spend your whole life trying not to get pregnant...

Michelle: Exactly.

Michelle's utterance is included in the avoiding disagreement strategy. By saying exactly, it indicates that she agrees what host's statement about her. 


\section{Data 12}

Host :And I love the story in the book where you pick up three month old Sasha and go to a job interview and you take her with you and you say to the interviewer, 'I'm a family woman, if you want me you need to have my family too and I need to be able to have flexible working.' That was way ahead of it's time.

Michelle: Well, that was an act of complete frustration and desperation because I also talk about how I had tried it so may be different ways.

Michelle's utterance is included in the avoiding disagreement strategy. Starting the conversation of Michelle by saying well it means that she wants to avoid disagreement between them.

\section{Data 13}

Host :And it's so brilliant that you did. I truly believe that flexible working is the only way we're going to get full equality in a workplace.

\section{Michelle: Absolutely.}

Michelle's utterance is included in the avoiding disagreement strategy. By saying absolutely, it indicates that she agrees and she wants to avoid disagreement.

\section{Data 14}

Host: So we did a social media competition where we got lots of people to send in the questions they wanted to ask you and we've got a winner from one called Natasha on Instagram. How do you manage to teach your children the same resilience that you've shown through your life when they have many privileges that you did not have growing up? And I was really interested in this one for my own children as well.

\section{Michelle: That's a very good question.}

Michelle's utterance is included in the Exaggerating (interest, approval, sympathy with H) strategy. The conversation happened when Michelle answer the question given by host and she shows exaggerating that she interests for what host wants by saying that's a very good question. 


\section{Data 15}

Host : Thank you very much. Another question lots of people asked was would you ever run for President of the United States but all I'm going to say to all those people is it is answered in the book!

\section{Michelle: Very clearly}

Michelle's utterance is included in the avoiding disagreement strategy. By saying very clearly, it indicates the utterance of Michelle that she wants to avoid disagreement to save threating face.

\section{CONCLUSION}

Virgin-Meet the Author is a Youtube channel whose episodes are videos about authors. This episode tells how the authors made their books and what the books contain. One of the authors on this episode is Michelle Obama. Researcher found that in Virgin-Meet the Author, the most widely used positive politeness strategy is the avoiding disagreement strategy. This shows that in communicating between the host and Michelle, Michelle mostly used avoiding disagreement strategies, the goal is to avoid any pressure on hearer's face and discomfort between her and her listener.

\section{REFERENCES}

Archia, J. J. (2014). A pragmatic analysis of positive politeness strategies as reflected by the characters in Carnage movie.

Ayuningrum, A., P, R.; \& S, S. (2018). An analysis of politeness stretegies apllied by the members, 2(4), 1-8.

Brown, P., \& Levinson, S. C. (1987). Politeness: Some universals in language use (Reissue). Cambridge University Press.

Cresswel, J. W. (2013). Research design_ qualitative, quantitative, and mixed method approaches (5th ed.). SAGE publications.

Dharmayanti, N. K. E., Sukarini, W. N., \& Savitri, W. P. (2018). Politeness strategies used in Ellen DeGeneres ' s TV talk show with Barack Obama as the guest star, 22, 142-146. https://doi.org/10.24843/JH.2018.v22.i01.p21

Gaspie, R. (2014). Politeness strategies in disagreement used by English department students of Muhammadiyah university of Surakarta.

Kamlasi, I. (2017). The positive politeness in conversations performed by the students of English study program of Timor university, $1(2)$.

Safitri, F. L. N. (2015). A study on politeness strategies of characters in the big wedding movie directed by Jusiti Zackham.

Sudaryanto. (2015). Metode dan Aneka Teknik Analisis Bahasa. Yogyakarta: Sanata Dharma 
University Press.

Supatmiwati, D., \& Abdussamad, Z. (2020). Equivalencein News HeadlinesTranslation: English Headlines Rendered into Bahasa Indonesia in BBC Web News. Humanitatis : Journal of Language and Literature, 6(2), 251-272. https://doi.org/https://doi.org/10.30812/humanitatis.v6i2.800

Yule, G. (1996). Pragmatics. Oxford University Press, USA. 
